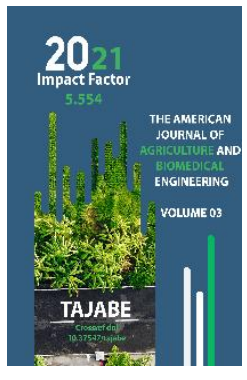

Journal Website: http://theamericanjour nals.com/index.php/taj abe

Copyright: Original content from this work may be used under the terms of the creative commons attributes 4.0 licence.

\section{Lepidoptera Found In Cabbage Agrobiocenosis The Dominant Types Of Representatives Of The Category Are Bioecology}

\section{B.A. Suleymanov}

Academic, Tashkent State Agrarian University, Uzbekistan

R.A. Jumaev

Professor, Tashkent State Agrarian University, Uzbekistan

L.A. Abduvosiqova

Associate, Tashkent State Agrarian University, Uzbekistan

\title{
ABSTRACT
}

This article aims to study the fauna of the South East region of Uzbekistan in the Lepidoptera category. Initially, representatives of the Pieridae, Plutellidae, Pyraliday and Noctuidae families were taken into account the composition of the species and their parasites. The first observations were made in the Bekabad and Boka districts. Lepidoptera is carried out on the identification of family representatives of the category Pieridae, Plutellidae, Pyraliday and Noctuidae. Many species of representatives of the first Pieridae family were identified.

\section{KEYWORDS}

Lepidoptera, Pieridae, Plutellidae, Pyraliday, Noctuidae, biosenosis.

type are pests that belong to the Lepidoptera category. In the absence of a

\section{INTRODUCTION}

In the last years, one of the vegetable crops, which the population of our country is growing on the scale of consumption, is considered a cabbage crop. Cultivation of cabbage crops suitable for ecological and consumer use is one of the most urgent manners of today. The main pests of the crop

fight against this category of pests, an average of $40-45 \%$ of vegetables, cereals and legumes grown in the Republic can die.

In particular, representatives of the Lepidoptera family of tunics, tins, moths of the Lepidoptera category are the most 
common Tangerines in the world. Autumn, wild, exclamation, Black-S tones from representatives of the only Noctuidae family are included in the variety of serious pests in vegetable crops.

If the only cabbage in the cabbage crop in the conditions of our country is not able to bring to the fight methods, caused by white butterfly, the season can lose an average yield of $35,2-46,6 \%$.

In agrobiocenosis, parasitic-heterozygous relations of the Lepidoptera category are important, which hold a special place in the relations of the boss in one rhythm. As a result of a sharp change in environmental factors, a violation of the balance between them leads to a mass increase in the boss.

\section{RESEARCH MATERIAL AND OBJECTIVE}

In our research we aimed to study the category of Lepidoptera in cabbage agrobiocenosis the fauna of the South East region of Uzbekistan. Initially, representatives of the Pieridae, Plutellidae, Pyraliday and Noctuidae families were included in the composition of the species and their parasites.

Observations were carried out mainly in Kibray, Bekabad, Buka, Ortachirchik, Kuychirchik and Zangiota districts of Tashkent region. In the sirdarya regions, cabbage crops were carried out in Saykhunabad, Agoltin, bakhtiyer and Yangiyer districts.

The first observations were made in the Bekabad and Boka districts. Because of the fact that both these districts are close to each other, it was assumed that the geographical distribution will be the same. Observations were compared by years, averaged indicators were obtained. Butterflies were caught using different handles, including light handles (BUF-30) and yeasts, and control was conducted every 3-5 days intervals, and butterflies of Lepidoptera group representatives who fell on the handles were collected and species composition was determined in the laboratory (Table 1).

\section{RESULTS}

As a result of the observations carried out on the identification of representatives of the family of Lepidoptera category Pieridae, Plutellidae, Pyraliday and Noctuidae in cabbage agrobiosenoes in the Bekabad and Boka districts of Tashkent region. 3 types of representatives of the first Pieridae family were identified. These are the species Pieris brassicae, Pieris rapae, Synchloe daplidice, the most common of these pests $(68,9 \%)$, the type Pieris brassicae became known as a result of research. From the family of Plutellidae it became known that cabbage meets one type in agrobiocenosis. This species was identified as a result of research that caused great economic damage to cabbage as pest Plutella maculipennis. There was a partial damage to the agrobiocenosis of cabbage that encountered loxostege Sticalis Pest from the Pyraliday Family (Table 1).

In the autumn of our studies, the most common types of pests that have undergone cabbage agrobiocenosis have turned out to representatives of the Noctuidae family. It became known that this family met Mamestra brassicae, Agrotis segetum, Agrotis exclamationis, Heliothis virihlaca, Autographa gamma, Agrotis ipsilon species. But among 
The American Journal of Agriculture and Boimedical Engineering

these species, it was found that Mamestra brassicae $(65,8)$ and Agrotis segetum $(34,6 \%)$, pests, causing the greatest damage to the cabbage crop and with the density of their population from other dominant species.

In observations over the years, the above pests were generalized and averaged indicators were obtained.

The level of occurrence of Representatives of the Lepidoptera category in cabbage crop

\section{1-Table}

The main representatives of the families of Pieridae, Plutellidae, Pyraliday and Noctuidae, which are found in the agrobiocenosis of the cabbage crop

(Tashkent region 2019-2021 yy)

\begin{tabular}{|c|c|c|c|}
\hline № & $\begin{array}{l}\text { Pests } \\
\text { Latin name }\end{array}$ & $\begin{array}{c}\text { Pests } \\
\text { Uzbek name }\end{array}$ & $\begin{array}{c}\text { Degree of } \\
\text { damage }\end{array}$ \\
\hline \multicolumn{4}{|c|}{ The Pieridae family } \\
\hline 1 & Pieris brassicae & Карам оқ капалаги & +++ \\
\hline 2 & Pieris rapae & Шолғом оқ капалаги & +++ \\
\hline 3 & Synchloe daplidice & Рапс оқ капалаги & ++ \\
\hline \multicolumn{4}{|c|}{ The family of Plutellidae } \\
\hline 1 & Plutella maculipennis & Карам куяси & +++ \\
\hline \multicolumn{4}{|c|}{ The Pyraliday family } \\
\hline 1 & Loxostege Sticicalis & Хаммахўр ўтлоқ парвонаси & ++ \\
\hline \multicolumn{4}{|c|}{ The Noctuidae family } \\
\hline 1 & Mamestra brassicae & Карам тунлами & +++ \\
\hline 2 & Agrotis segetum & Кузги тунлам & +++ \\
\hline 3 & Agrotis exclamationis & Ундов тунлам & + \\
\hline 4 & Heliothis virihlaca & Беда тунлами & + \\
\hline 5 & Autographa gamma & Гамма тунлам & + \\
\hline 6 & Agrotis ipsilon & Ипсилон тунлам & + \\
\hline
\end{tabular}

Comment: degree of lesion - (+++) multiple, (++ ) mid, (+) low.

The next stage of research was carried out in the districts of the Middle East and the Black fields varied over the years, with the population density changing. In order to determine whether the population density of Lepidoptera category vacuoles, large or small, studies were carried out on Cabbage agrobiocenoses planted in other districts and the degree of pest exposure was observed over the years. Cabbage crops are considered one of the most attractive and most harmful crops for some pests compared to other crops. 
of the Lepidoptera category Pieridae, Plutellidae and Noctuidae family were determined. Another 3 species of representatives of the first Pieridae family met the species Pieris brassicae, Pieris rapae, Synchloe dapiceice. Both Plutella maculipennis of the Plutellidae family were found to cause great damage by encountering a pest type. It became known that the population of this species is widespread in all regions of the Tashkent region. However, when Noctuidae came to family representatives, some differences from the Bekabad and Boka districts were observed during the studies. According to him, four species of the Noctuidae family were encountered in these regions. It turned out that these species are Mammastra brassicae, Agrotis segetum, Agrotis exclamationis and Autographa gamma species. By population density, it was found that Mamestra was brassicae $(60,2)$ and Agrotis segetum (36,8\%), pests ( 2 table).

Further research was carried out on the detection of tangential pests in the experimental fields of the Tashkent State Agrarian University and in the agrobiocenoses of the farmer farms of the Kibray District of the Tashkent region, which are designed to conduct special experiments in the experimental fields of the Tashkent State Agrarian University.

2-Table

The main representatives of the families of Pieridae, Plutellidae, Pyraliday and Noctuidae, which are found in the agrobiocenosis of the cabbage crop

(2019-2021 yy of sirdarya region)

\begin{tabular}{|c|c|c|c|}
\hline № & $\begin{array}{c}\text { Pest } \\
\text { species } \\
\text { Latin name }\end{array}$ & $\begin{array}{c}\text { Pest } \\
\text { species } \\
\text { Uzbek name }\end{array}$ & $\begin{array}{c}\text { Degree of } \\
\text { damage }\end{array}$ \\
\hline \multicolumn{4}{|c|}{ The Pieridae family } \\
\hline 1 & Pieris brassicae & Карам оқ капалаги & +++ \\
\hline 2 & Pieris rapae & Шолғом оқ капалаги & +++ \\
\hline 3 & Synchloe daplidice & Рапс оқ капалаги & + \\
\hline \multicolumn{4}{|c|}{ The family of Plutellidae } \\
\hline 1 & Plutella maculipennis & Карам куяси & +++ \\
\hline \multicolumn{4}{|c|}{ The Noctuidae family } \\
\hline 1 & Mamestra brassicae & Карам тунлами & +++ \\
\hline 2 & Agrotis segetum Den.et Schiff & Кузги тунлам & +++ \\
\hline 3 & Agrotis exclamationis & Ундов тунлам & + \\
\hline
\end{tabular}


The American Journal of Agriculture and Boimedical Engineering

(ISSN - 2689-1018)

I MPACT FACTOR

Published: June 30, 2021| Pages: 125-134

Doi: https://doi.org/10.37547/tajabe/Volume03lssueo6-17

2021: $5 \cdot 554$

OCLC - 1121105746

\begin{tabular}{|c|c|c|c|}
\hline 4 & Autographa gamma & Гамма тунлам & ++ \\
\hline
\end{tabular}

Comment: the degree of lesion- (+++) more, $(++)$ to the middle, (+) less.

For the purpose of conducting experiments, experiments were conducted to determine the pinkness of cabbage moth butterflies in the field of cabbage planting. Its three sections were isolated with a Entomological mesh (Table 3).

Then the cabbage was laid out on the separated fields during the growth period, 10 grains from the female butterflies, which were picked up and thrown out of nature from the collected buds. In the rest of the pieces, it was learned that the butterflies of the next generation are pink. In order to expand our research and clarify, experiments were conducted on the determination of cabbage white butterfly and cabbage tone raw beet. For this purpose, in the field of cabbage intended for special experiments, cabbage was laid out white butterfly shoots on isolated cabbage seedlings with a Entomological variety. The study was conducted between April and may and 3 returns. In this cycle, the air temperature was $+29+250$, and the relative humidity of the air was $+60 \%$.

\section{3-Table}

Determination of the pinkness of cabbage buns, cabbage tunics and cabbage white butterflies (TDAU experimental square, 2019-2021 yy)

\begin{tabular}{|c|c|c|c|c|c|}
\hline \multirow{2}{*}{ № } & \multirow[b]{2}{*}{ Types of pests } & \multicolumn{4}{|c|}{ Biological indicators } \\
\hline & & $\begin{array}{l}\text { Pedigree of } \\
\text { the female } \\
\text { breed } \\
\text { (PCs) }\end{array}$ & $\begin{array}{c}\text { Survival } \\
\text { (days) }\end{array}$ & $\begin{array}{l}\text { Gender } \\
\text { ratio (o': } \\
\text { ९) }\end{array}$ & $\begin{array}{c}\text { Degree of } \\
\text { damage to } \\
\text { the cabbage } \\
\text { crop (\%) }\end{array}$ \\
\hline 1 & Plutella maculipennis & 215 & 11.6 & $2: 6$ & 47,1 \\
\hline 2 & Pieris brassicae & 260 & 17.5 & $1: 4$ & 50,4 \\
\hline 3 & Mamestra brassicae & 180 & 13.8 & $1: 5$ & 38,2 \\
\hline $\begin{array}{l}\text { or } \\
\text { ido } \\
\text { ture } \\
\text { erv } \\
\text { Syr } \\
\text { bu } \\
\text { h th } \\
\text { tlar }\end{array}$ & $\begin{array}{l}\text { der to determine } \\
\text { ptera category and } t \\
\text { a in cabbage } \\
\text { ations were made in th } \\
\text { darya region. From the } \\
\text { tterflies of the pests } \\
\text { he help of light and fer } \\
\text { and eggs were collect } \\
\text { bservations. According }\end{array}$ & $\begin{array}{l}\text { types of } \\
\text { eir dominant } \\
\text { robiocenosis, } \\
\text { conditions of } \\
\text { pecified area, } \\
\text { ere collected } \\
\text { mon handles, } \\
\text { according to } \\
\text { o the results }\end{array}$ & $\begin{array}{l}\text { obtainec } \\
\text { segetum } \\
\text { gamma) } \\
\text { maculipe } \\
\text { brassica } \\
\text { brassica } \\
\text { cabbage } \\
\text { commor } \\
\text { over the }\end{array}$ & $\begin{array}{l}\text { utterflies of } \\
\text { gamma } \\
\text { Cabbage } \\
\text { is), Cabba } \\
\text { and cabbage } \\
\text { were obs } \\
\text { op seedling } \\
\text { pecies in ol } \\
\text { ars on cabba }\end{array}$ & $\begin{array}{l}\text { autumn night ( } \\
\text { night (Auto } \\
\text { Night } \\
\text { e Night (Ma } \\
\text { white butterfly } \\
\text { rved in tomo } \\
\text { (in may). The } \\
\text { servations con } \\
\text { ge crops were a }\end{array}$ \\
\hline
\end{tabular}


night (Agrotis segetum) 23,5\%, Cabbage Night (Mamestra brassicae), cabbage white butterfly (Pieris brassicae) butterflies. And relatively rare species of pests were found to be cabbage swabs (Plutella maculipennis), gamma night (Autographa gamma).

These tours are listed on account of the dominant species. Autumn night cabbage seedlings perished many of their germination in early spring. Also, a number of rodent pests were observed, which caused damage to the cabbage stem and root.
With the aim of expanding and clarifying our research, we have reaped the levels of these pest species encountered in the types of crops belonging to the species of bushel crops. These studies were carried out in shalghom agrobiocenosis of Kibray District of Tashkent region.

Our research on the identification of the main representatives of the Lepidoptera category has yielded its results. According to him, 8 types of Lepidoptera category representatives were found in shalgin agrobiocenosis.

\section{4-Table}

The main representatives of Lepidoptera category agrobiocenosis (Kibray District of Tashkent region" Salar Agromaks " farming 2019-2021 yy)

\begin{tabular}{|c|c|c|c|}
\hline № & $\begin{array}{c}\text { Pest } \\
\text { species } \\
\text { Latin name }\end{array}$ & $\begin{array}{c}\text { Pest } \\
\text { species } \\
\text { Uzbek name }\end{array}$ & $\begin{array}{c}\text { Degree of } \\
\text { damage }\end{array}$ \\
\hline \multicolumn{4}{|c|}{ The Pieridae family } \\
\hline 1 & Pieris brassicae & Карам оқ капалаги & +++ \\
\hline 2 & Pieris rapae & Шолғом оқ капалаги & +++ \\
\hline 3 & Synchloe daplidice & Рапс оқ капалаги & + \\
\hline \multicolumn{4}{|c|}{ The family of Plutellidae } \\
\hline 1 & Plutella maculipennis & Карам куяси & +++ \\
\hline \multicolumn{4}{|c|}{ The Noctuidae family } \\
\hline 1 & Agrotis segetum & Кузги тунлам & +++ \\
\hline 2 & Mamestra brassicae & Карам тунлами & +++ \\
\hline 3 & Agrotis exclamationis & Ундов тунлам & + \\
\hline 4 & Autographa gamma. L & Гамма тунлами & + \\
\hline
\end{tabular}

Comment: the degree of lesion- (+++) more, $(++)$ to the middle, $(+)$ less.

In the early turnip agrobiocenosis, it was found that mostly agrotis segetum, Mamestra brassicae, Pieris brassicae, Pieris rapae, Plutella maculipennystors were found to suffer a lot, 
while the relatively rare species were Autographa gamma, Agrotis exclamationis, Synchloe daplidice (Table 4).

These pests are mostly encountered in the fairy-tale shalgum crop, it became known that many species of shalgum cause damage during the vegitation period. Mainly the first generations of pests encountered a lot in the shalgom crop, and the next generations became known to pass on agricultural crops of other types as well as cabbage crops.
As a result of the research, the types of pests that can cause great economic damage to the cabbage crop have been identified. It became known to them that cabbage is a white butterfly, cabbage anthills and cabbage tones.

In order to clarify the above information, we conducted our research and examined the levels of pest species that are causing damage in cabbage agrobiocenosis in the exact \% of the South East regions of Uzbekistan (1-fig).

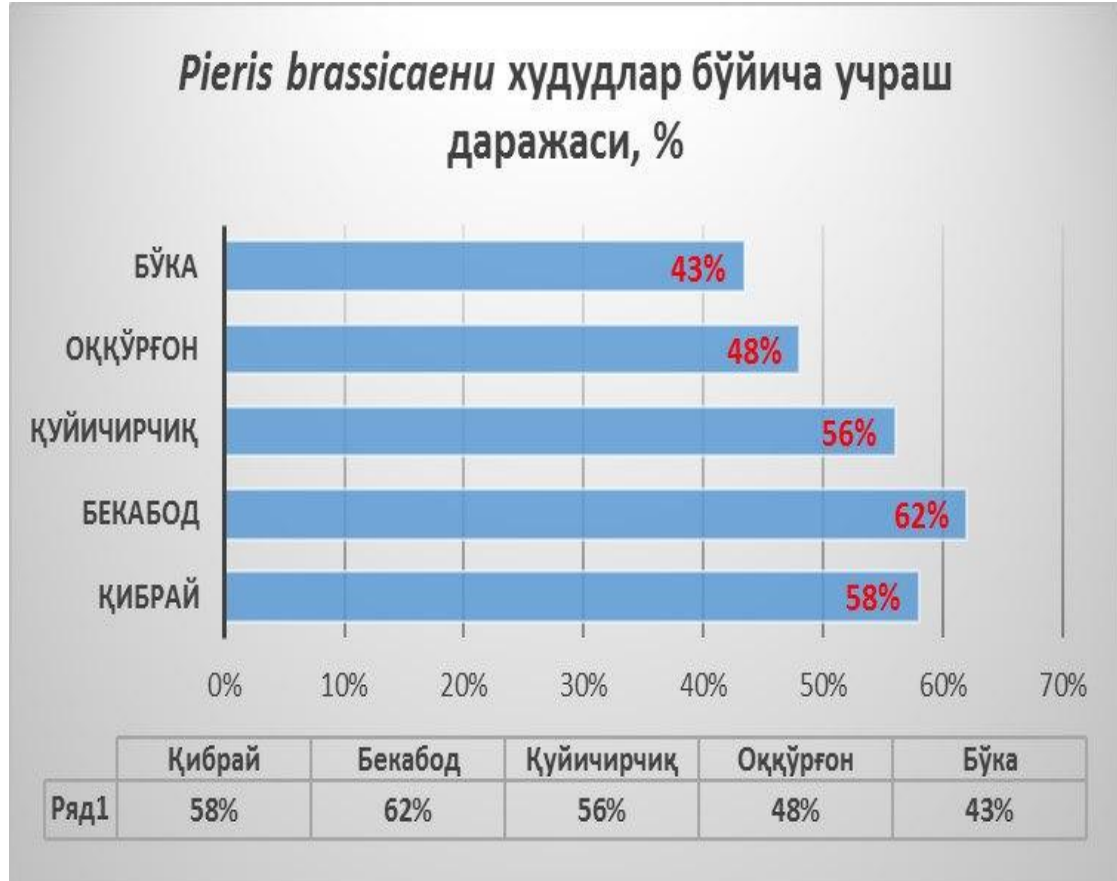

1-fig. Cabbage in different regions of Tashkent region

cabbage white butterfly (Pieris brassichae) level of meeting type. (2019-2021 yy).

The research works carried out in 2017-2019 were summarized and mean scores were given. These types of pests have spread all over our country in a variety of ways, and the prevalence and good development of these species in the same region is inextricably linked to the bioecology of these species of pests, and in our research we aimed to also study the spread of cabbage white butterfly in 
the regions, one of the main representatives of the Lepidoptera

The first researches were carried out on the farms of farmers specializing in vegetable growing in Tashkent region. Constant exposure of cabbage white butterfly (Pieris brassicae) in agrobiocenosis of cabbage has been studied in different climates in comparison with other types of pests of cabbage crop. According to him, this species was reported to be $57.8 \%$ in kibray district cabbage agrobiocenosis, $61.6 \%$ in Bekabad district, $56.2 \%$ in Kuyichirchik district, $47.6 \%$ in Akkurgan district and $43.4 \%$ in Boğka district.
These studies were carried out in parallel in four districts of Sirdarya region in cabbage agrobiocenoses.

According to him, agrobiocenoses of cabbage planted in Saykhunabad, Akultin, bakhtiyer and Yangiyer districts for 3 years were considered the level of meeting representatives of Lepidoptera category. According to the results of our studies, it was determined that up to $41.6 \%$ in Sayhunabad district, 47.9\% in Akultin district, 27.1\% in Bakht district and $30.7 \%$ in Yangier district suffer from cabbage white butterfly (Pieris brassicae) type cabbage agrobiocenosis compared to other types of pests. (2-fig).

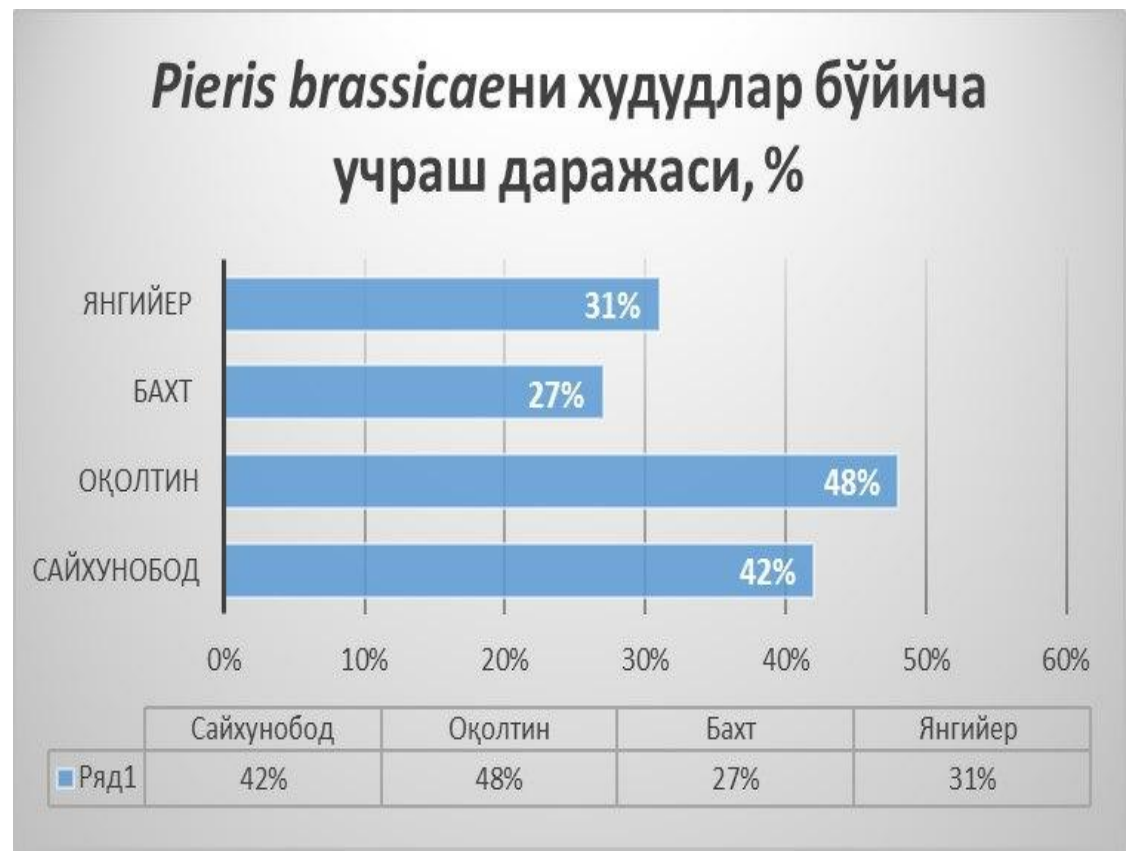

2-fig. In different regions of sirdarya region

cabbage white butterfly in cabbage crop (Pieris brassicae)

level of meeting type. (2019-2021 yy)

From the results of the research it became known that the increase of cabbage white butterfly in Syrdarya biosenosis was different than in Tashkent biosenosis. Sirdarya region due to its slightly lower relative humidity than in Tashkent region, there was discomfort in 
the development of white cabbage butterflies, and the degree of pest infestation is lower than in the Tashkent region where the level of pest infestation is lower than that of cabbage agrobiocenosis, but the degree of pest infestation is higher than that of cabbage

\section{CONCLUSION}

From the above studies it became known that as a result of the determination of the dominant species in the cabbage crop, the white cabbage showed a high indicator. According to him, Cabbage night was reported to be in the Bekabad District of Tashkent region at a high level (61.6\%) compared to other districts in cabbage agrobiocenosis. This type of cabbage agrobiocenosis in the Boka District of Tashkent region has a minimum incidence (43.4\%) compared to other districts. According to the results of studies on the territory of sirdarya region, in the Agoltin district, cabbage agrobiocenosis was $47,9 \%$ more common than in other districts. This indicator was $27.1 \%$ in the case of agrobiocenosis of cabbage in the region of happiness of the Syrdarya region with low incidence. And below we have listed natiches of our studies on the determination of the degrees of soreness and soreness indicators of cabbage tarragon (Plutella maculipennis) and cabbage (Mamestra brassicae)on the territory. In order to continue the observations of the autumnal part of our studies on Cabbage night, the degree of germination of this pest in the cabbage crop was determined. To do this, the Flying period of Cabbage Night butterflies was determined with the help of sexual feramon handles, fixed on an area of 0.2 hectares every 1 grain, inside
$10 \mathrm{~m}$ of the crop. The mounted handles were checked every day. The studied the variability of cabbage nighttime 2-generation butterflies in the cabbage crop, depending on the duration of the flight and the degree of pinkness. Cabbage Night butterflies in the cabbage field 2-th generation began to fly in the first ten days of June. Their gross flying period coincided with the second decade of this month. In the period of gross flight, in one day, butterflies fell on the handles up to 3-4 pieces. At the same time, the pinkness of the butterflies increased. In order to determine their degree of pinkness, only 2-th generation of Cabbage Night butterflies were observed in the amounts of laying eggs. Because in cabbage, mainly the second generation of Cabbage Night butterflies causes great economic damage.

The laying of eggs of the second generation of butterflies lasted up to 30 days and went. According to him, the laying of eggs in butterflies was observed on 5-day 3,5 pieces, on 10-day 8.6 pieces, on 15-day 12.4 and on 20day 23,7 pieces. Then by 22-day, on average in every 100 Bush made up 11,6 and 30-day, while in the sharp decline 5.2 grains. During this period, the air temperature and relative humidity of the air were also observed, which was compared with the pinkness of the butterflies. For the second generation, the air temperature was $+31,1+2^{\circ} \mathrm{S}$ on average, while the relative humidity of the air was $48,2 \%$. In the period of the gross flight of Cabbage Night butterflies in the fairy-tale cabbage crop, the air temperature rose to an average of $+41+2^{\circ} \mathrm{C}$ in the daytime, and at night it was $+23,4+3^{\circ} \mathrm{S}$ on average. From the above research, it was found that these indicators can be attributed to the nutritional 
environment of the butterflies, correlating this state with the fact that the cabbage crop corresponds to the period in which it was grossly harvested.

\section{REFERENCES}

1. Abbots W.S. A method of computing the effectiveness of insecticide, -1925.V.18. - №3. - P. 265-267.

2. Анорбаев A.P. Trichogramma chilonis Ishii нинг морфологик белгилари // Ж. Вестник Каракалпакского государственного университета им. Бердаха. -Нукус, 2011. №1(10) - С. 2830.

3. Жумаев P.A. In vitro rearing of trichogramma (Hymenoptera: Trichogrammatidae) // European Science Review № 9-10. Austria, Vienna 2016. -Б. 11-13.

4. Жумаев Р.А. Массовое размножение трихограммы на яйцах хлопковой совки в условиях биолаборатории и ее применение в агробиоценозах // Халқаро илмий-амалий конфренция “Ўзбекистон мева-сабзавот махсулотларининг устунлиги" мақолалар тўплами. Тошкент:2016 -Б. 193-196.

5. Жумаев Р.А. Значение представителей семейства BRACONIDAE B регулировании численности совок в агробиоценозах // ЎзМУ Хабарлари. 2017. №3/1. -С. 67-70.

6. Жумаев Р.А., Кимсанбоев Х.Х., Адилов M.M., Рустамов A.A. The technology of rearing Braconidae in vitro in biolaboratory // European Science Review. № 3-4. Austria, Vienna 2017 -Б. 3-5.
7. Жумаев

P.A.,

X.X.

Кимсанбаев.Технология размножения Bracon hebetor Say методом in vitro в биолаборатории // Актуальные вопросы современной науки. Научный журнал № 2(14) апрель 2017 -С 50-54.

8. Жумаев Р.А. Размножения ин витро Bracon hebetor Say В Bracon greeni Ashmead // Актулъные проблемы современной науки. Информационноаналитический журнал № 3(94). 2017 й. -С 215-218.

9. Кимсанбаев. Х.Х., Жумаев Р.А. Renewing and rearing technology of Bracon hebetor Say in Biolaboratory Материалы VIII-оймеждународной научно - практической конфе-ренции молодых исследователей, г. Волгоград, 2014. -С. 257-260.

10. Кимсанбаев Х.X, Сулаймонов Анарбаев А.Р., Ортиқов У.А., Сулаймонов О.А., Жумаев Р.А., Ахмедова 3.Ю. Биоценозда ўсимлик зараркунандалари паразит энтомофагларини ривожланиши. «O'zbekiston» НМИУ, -Тошкент: 2016. Б. 235

11. Li, Li-Ying. Liu Wenhui, Chen Chaoshian, Han Shitzou, Shin Jiachi, Du Hansun, Feng Shuyi. In vitro rearing of Trichogramma spp, and Anastatus sp. In artificial "eggs" and the methods of mass production. Parasitiods and predators (insecta) of agricultural and forestry arthropod pests. Guangdong Entomological Institute. -1997. -P. 344357.

12. Li Li-ying. In vitro rearing of parasitoids of insekt pests in China. Parasitiods and predators (insecta) of agricultural and forestry arthropod pests. Guangdong 
Entomological Institute. -1997. -P. 363369.

13. Li, Li-Ying. On sibling relationship among some species trichogramma. Parasitiods and predators (insecta) of agricultural and forestry arthropod pests. Guangdong Entomological Institute. 1997. -P. 22-24. 